\title{
A Study on Developing a Guide Material for Science Classes Supported by Out-of-School Learning ${ }^{i}$
}

\author{
Büşra Bakioğlu* , Orhan Karamustafaoğlu \\ Faculty of Education, Amasya University, Turkey
}

Copyright $\subset 2017$ by authors, all rights reserved. Authors agree that this article remains permanently open access under the terms of the Creative Commons Attribution License 4.0 International License

\begin{abstract}
The main purpose of this research was to develop a guide material in line with learning outcomes of the unit for the $5^{\text {th }}$ Graders titled Solving the Puzzle: Our Body in order to be utilized during out-of-school learning activities by science teachers. There is no guide material developed in our country for science teachers to be used in out-of school learning activities. This research intended to contribute to the literature by developing such guide material. This research utilized the screening model. Prior to the development of a guide material, the literature has been reviewed to identify units and subjects for which guidance material is designed for. Moreover, the guide material is developed after completing the needs analysis, identifying the objectives and learning outcomes, organizing the content and learning activities and deciding on how to make assessment and evaluation. This research was designed to help develop guide materials that include other units related to out-of-school learning activities for different grade levels and for different classes.
\end{abstract}

Keywords Out-of-School, Learning Environment, Science Teacher, Guide Material

\section{Introduction}

Raising individuals who can make use of knowledge in their daily life, by being more productive and thus can contribute to the overall production process is thought to be possible in environments where the education is at the closest point to the reality because of the rapidly growing technology and easier access to the information [1]. This means that students cannot actualize their education and training if it is conducted only between school walls. Hence, today, out-of-school learning environments are very much needed.

Studies on out-of-school learning environments in Turkey have been attracting popular interest [2, 3, 4, 5, 6, 7, 8]. Although out-of-school learning is considered as informal, they are formally conducted processes. In other words, out-of-school learning environments have both formal and informal (out-of-school but unplanned) educational aspects [9]. In this regard, Maarschlak [10] and Tamir [11] classified learning environments into three groups as formal, non-formal and informal; and they regarded the out-of-school learning environments as non-formal (still based on a plan)- learning environment [12].

Out-of-school environments offer a rich variety of learning opportunities for students, as well as help them configure the information they have learned through concrete examples [4]. Additionally, it strengthens the social skills of the students and contributes to the development of their science skills [13]. On the contrary, out-of-school learning environments can be perceived only as entertaining, sightseeing activities by students and teachers [14]. In this regard, teachers, who would like to lecture in out-of-school environments, should be well informed about what needs to be done in such environments in order to have an effective and efficient class. Hence, guide materials about how to lecture a class in out-of-school learning environments are very much needed. According to Demircioğlu, guide materials are useful for teachers since they can read the content and method beforehand, and thus can facilitate the class more easily and use the time more efficiently throughout the course [15]. In order to increase the use of guide materials that are necessary for a well-planned learning process, teachers and pre-service teachers should benefit from various examples of guide materials and then make the implementation of content accordingly [16]. In the literature, it has been found that teachers expressed concerns about having insufficient knowledge and lacking self-sufficiency regarding trips to out-of-school environments; and they stated that they are not sufficient to guide students during these trips [17, 18, 19, 20, 21].

Curriculum for Science Classes, which is revised in 2013, was prepared based on the "research and questioning" approach. According to this curriculum, teachers are required to organize both in-class and out-of-school learning environments based on research and questioning strategy. Incorporate science, art and archeological museums, zoos 
and natural habitat can be used as informal learning environments, which may help students make sense of scientific knowledge and facilitate permanent learning [22]. As the Curriculum for Science suggests, science teachers should pedagogically benefit from out-of-school environments. When the related literature in Turkey was reviewed, it was found that science-arts centers, zoos, nature camps, and the museums are the focal points for out-of-school learning $[9,23,24,25]$. In the respective literature there is no guide material for teachers to be used in out-of-school environments for the fifth grade unit to be used in Science classes [26]. In this regard, we have aimed to contribute to the literature by developing a guide material, named as Solving the Puzzle: Our Body, in line with the learning outcomes of the fifth grade units according to the Curriculum of Science classes revised in 2013.

\section{Materials and Methods}

\subsection{Methods}

The research was conducted through the document analysis method. Document analysis involves the analysis of materials like books, videos, photos etc. related to the research topic [27]. This method is used when it is not possible to have observation or interviews; however, it can also be used to support the observation and interview results [28]. Therefore, this study utilized the document analysis. Curricula of different countries were reviewed, and various other documents were examined to understand in which ways out-of-school learning is included in the curricula. Constitutive units and subjects for the guide material were determined after studying the Curricula for Science Classes in Turkey (revised in 2013). Then, the needs analysis was completed, the objectives and learning outcomes were identified, the content and learning activities were organized and assessment and evaluation methods were decided and lastly the guide material was developed.

\subsubsection{Development Process of the Guide Material}

Development process of the guide material is presented in Table 1. The revised science curriculum was examined in terms of objectives and learning outcomes for the $5^{\text {th }}$ grade unit titled Solving the Puzzle: Our Body. Additional required learning outcomes were included in this study by the researcher. An objective analysis was conducted for each outcome. The methods of lecturing the unit were examined in the existing course book parallel to these outcomes. The course book is the Elementary School Science Course Book for the $5^{\text {th }}$ grade students, which is the same everywhere in the country.

The prepared unit consists of 13 learning outcomes in 2013 Curricula for Science Classes. It has 3 subtopics: Nutrients and Their Characteristics, Digestion of Nutrients and Digestion in our Body (MEB, 2013). The research adds 7 more learning outcomes that make 20 learning outcomes in total for this unit. These outcomes were examined, out-of-school environments for lectures were identified and related guide material was developed.

Visual materials were exclusively included in the all out-of class activities to make the subjects more comprehensive for students. Moreover, brochures, which provide information about the places to be visited, were distributed to students before the trip. Forms were prepared to be filled during the trip by students. Additionally, experiments and analogies were occasionally used during activities.

The first part of the unit covers the topic "Nutrients and Their Characteristics". In the Curriculum for Science Classes, the recommended time to complete this section is 12 course hours. There are 6 learning outcomes for this section in the existing curriculum. In the guide material, there are 10 learning outcomes for this section, including 4 additional learning outcomes identified by the researcher. For the topic "Nutrients and Their Characteristics", there are 3 out-of-school environments planned for lectures. Learning outcomes and respective out-of-school environments are presented below in Table 2 . 
Table 1. Development Process of the Guide Material

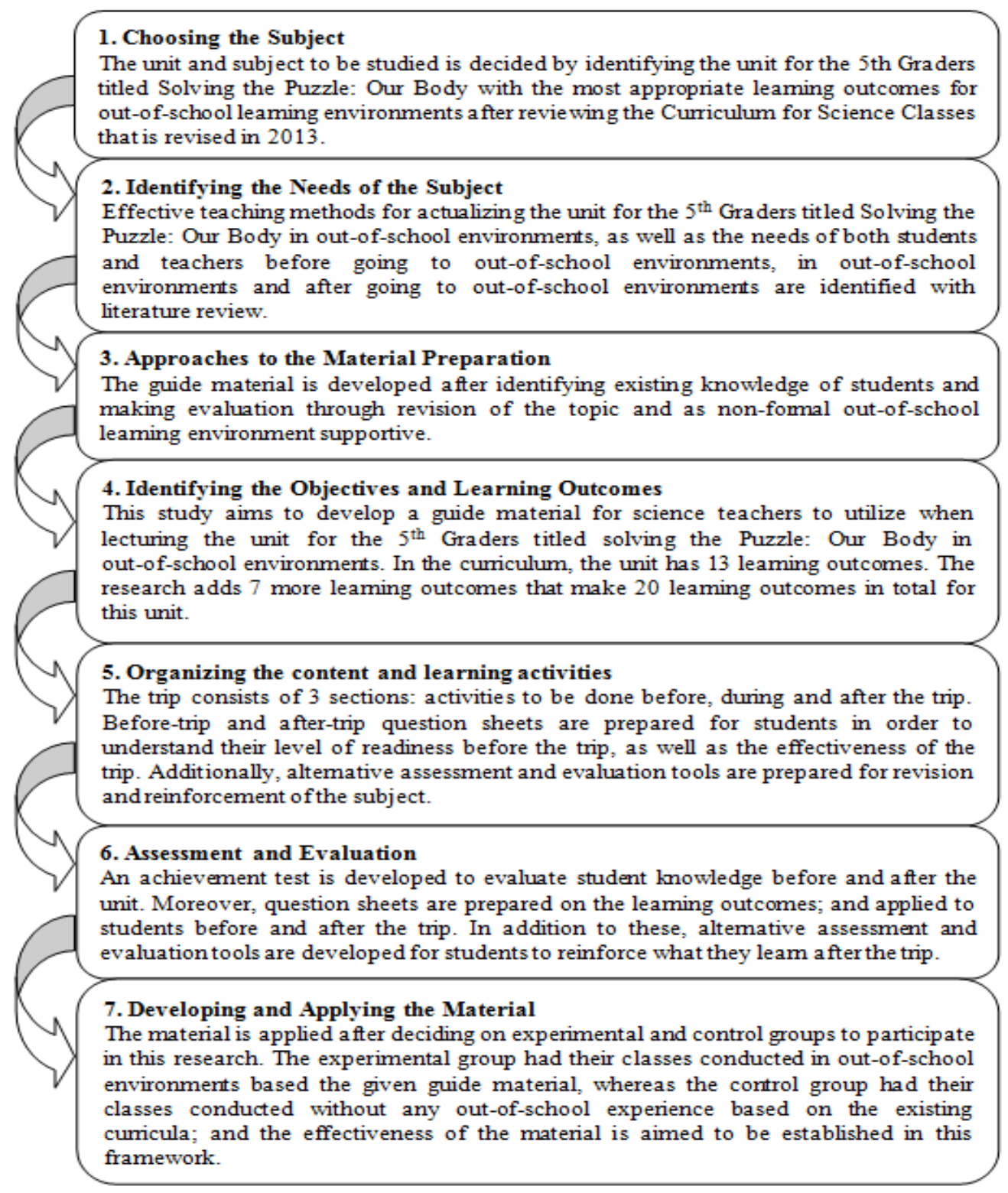

Table 2. Learning outcomes for the topic "Nutrients and Their Characteristics" and respective out-of-school environments

\begin{tabular}{|c|c|}
\hline Learning Outcomes & Respective out-of-school environments \\
\hline $\begin{array}{l}\text { 5.1.1.1. Recognizes that nutrient ingredients are necessary for vital activities of the living beings. } \\
\text { 5.1.1.3. Infers that the water and minerals exist in all nutrients. } \\
\text { data from the investigation. }\end{array}$ & - Picnic in the school garden \\
\hline $\begin{array}{l}\text { 5.1.1.2. Investigates and presents which nutrients have the most vitamin varieties. } \\
\text { 5.1.1.4. Investigates and presents the effects of a balanced nutrition on human health. } \\
\text { 5.1.2.7. Recognizes the importance of balanced and regular diet for human health.* } \\
\text { 5.1.1.7. Knows possible diseases that may develop in our body in vitamin deficiency.* }\end{array}$ & $\begin{array}{l}\text { Department of Nutrition and Dietetics } \\
\text { (Dietitian) }\end{array}$ \\
\hline $\begin{array}{l}\text { 5.1.1.6. Discusses the damages of cigarette and alcohol consumption on our body based on the } \\
\text { data from the investigation. } \\
\text { 5.1.1.7. Discusses the dangers of smoking and alcohol.* } \\
\text { 5.1.1.8. Gives examples from the daily life about the dangers of smoking and alcohol.* }\end{array}$ & $\begin{array}{l}\text { - Faculty of Medicine- Department of } \\
\text { Pediatrics }\end{array}$ \\
\hline
\end{tabular}

*Learning outcomes that were added by the researcher 
The second part of the unit covers the topic "Digestion of Nutrients". In the Curriculum for Science Classes, the recommended time to complete this section is 12 course hours. There are 4 learning outcomes for this section in the existing curriculum. In the guide material, there are 6 learning outcomes for this section, including 2 additional learning outcomes identified by the researcher. For the topic "Digestion of Nutrients", there are 2 out-of-school environments planned for lectures. Learning outcomes and respective out-of-school environments are presented below in Table 3.

The third part of the unit covers the topic "Digestion in Our Body". In the Curriculum for Science Classes, the recommended time to complete this section is 12 course hours. There are 3 learning outcomes for this section in the existing curriculum. In the guide material, there are 4 learning outcomes for this section, including 1 additional learning outcome identified by the researcher. For the topic "Digestion in Our Body", there is 1 out-of-school environment planned for lectures. Learning outcomes and respective out-of-school environments are presented below in Table 4.

The guide material was examined by 3 faculty members and 2 science teachers before its application. Then, the missing parts were completed and the material was finalized and made ready to use according to the feedbacks of faculty members and science teachers.

\subsubsection{Sections of the Guide Material}

This guide material was developed for the teachers who want to lecture this unit (Solving the Puzzle: Our Body) in out-of-school environments as supportive material. In order to achieve the learning outcomes, six lectures and activities were designed to be conducted in out-of-class environments. The names of these out-of-school environments and activities are listed below:

- $\quad$ Picnic- I am having my breakfast

- Dietitian- I have balanced and regular diet nutrition

- Faculty of Medicine Department of Pediatrics- I learn about dangers of smoking and alcohol consumption.

- Faculty of Medicine Department of Gastroenterology- I learn about the digestive system in details

- Oral and Dental Health Clinics -I love my teeth

- Dialysis Center- My kidneys are precious

\subsubsection{Use of the Guide Material}

The guide material is consisted of 6 activities within the scope of the unit titled Solving the Puzzle: Our Body. As an example, the activity named "I am having my breakfast." is presented in the Appendix-1.

The guide material for out-of-school learning consists of 3 parts: things to do before, during and after the trip.

Table 3. Learning outcomes for the topic "Digestion of Nutrients" and respective out-of-school environments

\begin{tabular}{|c|c|}
\hline Learning Outcomes & Respective out-of-school environments \\
\hline $\begin{array}{l}\text { 5.1.2.1. Shows where organs and structures responsible for digestion } \\
\text { are placed on the model in respective order. } \\
\text { 5.1.2.6. Explains the concept of digestion.* } \\
\text { 5.1.2.4. Infers that nutrients are transported around the body through } \\
\text { blood after digestion. }\end{array}$ & - Faculty of Medicine- Department of Gastroenterology \\
\hline $\begin{array}{l}\text { 5.1.2.2. Shows tooth types on the model and explain their function. } \\
\text { 5.1.2.3. Pays attention to nutrition, hygiene and regular dental control } \\
\text { for dental health. } \\
\text { 5.1.2.5. Uses the tooth brush appropriately.* }\end{array}$ & - $\quad$ Oral and Dental Health Clinics \\
\hline
\end{tabular}

*Learning outcomes that were added by the researcher

Table 4. Learning outcomes for the topic "Digestion in Our Body" and respective out-of-school environments

\begin{tabular}{|l|l|}
\hline Learning Outcomes & Respective out-of-school environments \\
\hline $\begin{array}{l}\text { 5.1.3.1. Recognizes structures and organs responsible for digestion. } \\
\text { 5.1.3.2. Infers that there are different digestion processes in our body } \\
\text { and toxic substances produced after digestions are required to } \\
\text { thrown out of the body. }\end{array}$ \\
$\begin{array}{l}\text { 5.1.3.3. Investigates and presents what needs to be done to protect } \\
\text { kidneys. }\end{array}$ \\
$\begin{array}{l}\text { 5.1.3.4. Recognizes that healthy kidneys require 1-1.5 liter daily } \\
\text { water consumption on average.* }\end{array}$ \\
\hline
\end{tabular}

*Learning outcomes that were added by the researcher 


\section{a. Things to do before the Trip}

Things to do before the trip include necessary preparations for the out-of-school environment for this trip.

1. Brochures: They are prepared to provide information for students about the out-of-school learning environment, as well as the activities to be done during the trip. Brochures include sections of "What are we going to learn?", "What are we going to do before going to the trip?", "What are we going to do during the trip?" and "Rules". These sections are prepared as to be a small plan of the trip. The purpose of preparing brochures is to help students get information about the place that they will visit. After teacher completes bureaucratic procedures (such as permissions of parents and school administration), S/he should distribute the brochure of the trip to students a couple of days prior to the trip.

2. Pre-and Post-Trip Question Sheet; Before-trip and after-trip question sheets includes open and closed ended questions about the information and skills that are expected to be acquired by students. These question sheets are developed to understand whether students efficiently benefit from the trip by distributing the question sheets both before and after the trip. Moreover, this helps to guide the trip on the basis of needs of students by measuring their prior knowledge.

3. The Guide Material: It is prepared for teacher to have a well-organized and planned trip. It is a program including unit name, learning domain, subject, duration, method and technique, grade, critical skills to be achieved by students, materials, learning outcomes, application of activities, results, activities to do in classroom after the trip, and methods of assessment and evaluation. Teacher should examine the guide material before going to the trip. Necessary appointments with the institution to be visited should be made before the trip and the personnel that will accompany teacher during the trip should be informed about the flow of the class. Teacher should direct the flow of the class during the trip by using the guide material.

\section{b. Things to do during the Trip}

1. Forms about the trip: They are distributed to students before the trip to be filled during the trip and returned to the teacher after the trip. The question flows in question sheets are prepared by taking the guide material into account. The purpose of preparing forms about the trip is to keep students vigilant during the trip. Moreover, they can make notes of interesting things they encounter during the trip. Students are responsible for filling in these forms during the trip.

2. Have Fun and Learn Cards: They are prepared for objects found during the trip. The empty spaces on cards are filled by students. These cards are only used during the trip to the Faculty of Medicine Department of Gastroenterology. There are pictures of organs of the digestive system. Students are asked to write the name and their function on these cards after finding them during the trip. These cards can be used for the purpose of repetition at the last step of the trip. An example of Have Fun and Learn Cards is provided in Picture 1.

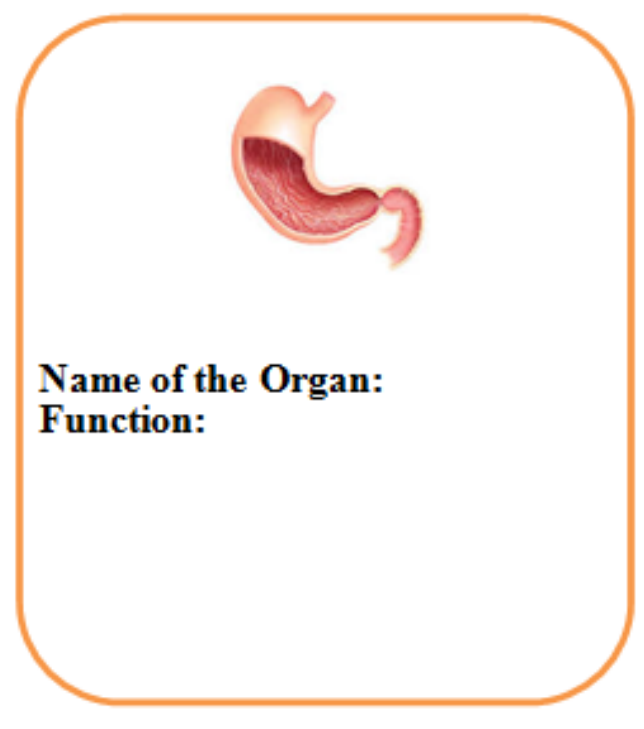

Picture 1. An Example of Have Fun and Learn Card

\section{c. Things to do after the Trip}

They include alternative assessment and evaluation tools to reinforce knowledge and skills gained during the trip.

1. Concept maps: They are maps prepared to revise, summarize or assess and evaluate the knowledge gained during the trip. The purpose of using concept maps changes on the will of the teacher. When coming all together in classroom after the trip, concept maps presented in the guide material can be filled in all together for the purpose of repeating or summary. If the teacher wants to use concept maps for assessment and evaluation, s/he can give points to answers.

2. Knowledge maps: They are maps prepared to revise, summarize or assess and evaluate the knowledge gained during the trip. Like concept maps, knowledge maps can also be filled in all together after coming in the classroom after the trip for the purpose of repeating or summary. If the teacher wants to use knowledge maps for assessment and evaluation, s/he can give points to answers.

3. Structured Grids: They are questions prepared to revise or assess and evaluate the knowledge gained during the trip. Structural grips can also be graded by making each student fill them in, as well as for repeating or assessment and evaluation after coming in the class.

4. Diagnostic Trees: They are questions prepared to assess and evaluate the knowledge gained during the trip. Grading can be completed by distributing diagnostic trees to students one by one.

\section{Results and Suggestions}

Recently interests in out-of-school learning environments 
have being raised among the researchers in Turkey. In 2013 Curriculum for Science Classes, it is expressed that teachers should benefit from out-of-school environments. In this regard, a guide material is developed for science teachers to utilize when lecturing the unit titled Solving the Puzzle: Our Body in out-of-school environments. Nowadays, out-of-school learning environment is considered as complementary of formal education [29]. Moreover, such environments help students gain affective, psychomotor and social skills, as well as improve their academic success [30, $31,32]$. In this regard, teachers should plan trips very well in order to have effective lectures [14]. It is thought that this guide material would help teachers to lecture about respective units in out-of-school environment.

In the literature, the studies on the guide materials for out-of-school environments are in adequate, since most of the studies about the out-of-school environments are conducted in science-arts centers, zoos and nature camps [6, $23,25]$. Hence, this guide material aims to contribute to the literature in this sense.

Based on the results of this research, the following suggestions have been made to academicians, researchers and teachers.

- It is thought that the curricula for teacher-training schools should include classes about out-of-school learning and pre-service teachers should practice out-of-school learning during these classes.

- The guide material developed in this study can be applied to various units, grades and lessons to contribute to the literature.

- $\quad$ Out-of-school learning environments can be promoted by explaining this subject to the existing teachers and administrators through in-service training activities.

- $\quad$ Out-of-school learning environments in line with each unit and learning outcomes should be indicated in the textbooks and warning signs can be placed to carry out the teaching in these environments.

\section{Appendix 1}

\section{Activity-1 I am Having My Breakfast}

In order to introduce the trip to students, a brochure should be prepared and distributed to students a couple of days prior to the trip. Question sheets that are prepared to understand the level of readiness by the students before the trip should be distributed and answered by students. Moreover, these question sheets should be redistributed among students after the trip in order to observe the differences between student answers before and after the trip.

\section{Pre-and Post-Trip Question Sheet- Breakfast}

Answer the following questions in the given spaces below.

\section{Why do people feed themselves?}

2. How many vitamins are there? Give one example from the nutrients for each vitamin you know.

3. What are the things that we should pay attention when buying nutrients?

Picnic in the School Garden

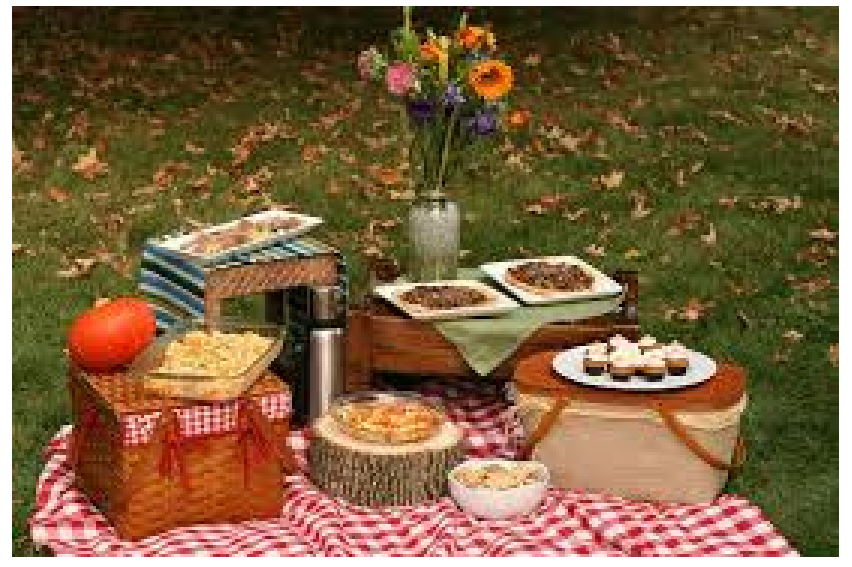

On this trip, we will have our breakfast in the school garden with the food we brought.

During this picnic, you will both have fun and learn information through guidance of your teacher.

\section{What Will We Learn?}

Nutrient ingredients are necessary for vital activities of all living beings,

Water and minerals exist in all nutrients,

Fresh and natural nutrients are very important for a healthy life.

\section{What Are We Going to Do before the Trip?}

Before the trip, you will answer questions from the pre-trip question sheet distributed by your teacher. You are also expected to bring food with you on the specified day. 


\section{What Are We Going to Do during the Trip?}

You will fill in the form about the trip distributed by your teacher. You are also expected to participate in activities.

\section{What Are We Going to Do after the Trip?}

After the trip, you will answer questions from the post-trip question sheet distributed by your teacher.

\section{Rules}

Everyone will bring food for breakfast with them for the trip.

Everyone will follow their teacher's instructions.

Everyone will carefully listen what their teacher explains and try to fill in answers for the worksheet as much as possible.

\section{$\odot$ Wish You All an Enjoyable and Educative Trip}

\section{Guide Teaching Program for Teachers $-1$}

Unit: Solving the Puzzle: Our Body
Learning Domain: Living Species and Life

Subject: Nutrients and Their Characteristics

Duration: 5 Course Hours $(40+40+40+40+40)$

Method/Technique:

Question-Answer,

Visit-Observe-Evaluate, Brainstorming

Grade: 5

Critical skills to be achieved by students: Relating what they learn with their daily life, critical thinking

Materials: Worksheet (Activity 1), brochure, concept maps, knowledge maps, structured grids, diagnostic trees, food for breakfast, fork, glass, napkin, tablecloth, bottled water.

Before starting this unit, pre-existing knowledge of students should be tested. The unit titled "Solving the Puzzle: Our Body" also exists in 4th Grade Science Classes. The lecture should start only after testing the pre-existing knowledge of students and completing shortfalls.

Students should be informed that there will be breakfast at school for the following class. In this regard, they are asked to bring foods that they have for breakfast at home to school. The teacher should also bring food for breakfast that is appropriate for a balanced and regular diet. Additionally, the teacher should also distribute the brochure prepared to introduce the place to visit, as well as the lecture, to students before the trip.

\section{OUTCOMES}

\subsubsection{Recognizes that nutrient ingredients are necessary for vital activities of the living beings.}

\subsubsection{Infers that the water and minerals exist in all nutrients.}

5.1.1.5. Discusses the importance of fresh and natural nutrients for a healthy life based on the data from the investigation. 


\section{Activity 1: I Am Having My Breakfast}

Introduction: Students come to lectures with their breakfasts. If the weather is nice outside, students may have their breakfast as a picnic in the school garden.

Progress: The teacher asks students to take out their food for breakfast. S/he also takes out her/his own food appropriate for a balanced and regular diet. In the meanwhile, the teacher distributes the respective question sheets to students.

S/he asks students "what happens if people do not eat". This question and answer session continues until teacher receives answers like "we will not be able to run around or play or do anything if we do not eat". A student asks teacher "I fasted many times. I had glaze over towards evening. I felt weak. Why does this happen when we do not eat?”. The teacher redirects this question to students. The students are expected to provide answers like we will not be able to function as a living organism if we do not eat. The teacher stresses that we need to eat in order to continue with our vital body functions like talking, walking and breathing. The teacher explains that as cars do not work without gas, people cannot function as living organisms without eating and directs another question to the students. The teacher instructs the students to fill in the respective parts on the form with the food they brought. Students fill in these parts.

\section{EXAMPLE:}

Begüm’s Menu: Milk, Tomato, Cheese, Bread

Umut's Menu: Olives, Chocolate Cream, Fruit Juice, Savory pastries

Yağmur's Menu: French fries, Apple, Jam, Turkish Bagels

Yiğithan's Menu: Skim-milk cheese, Ice tea, Honey, Butter, Cake, Bread

Teacher asks if students brought fresh food and whether they washed them. Teacher asks the class "What happens if we do not wash our food and pay attention to their freshness?". Students write their answers in the respective parts of the forms about their trip. One student comments as "I saw plums on the tree when I visited my grandparents and I craved for them. I ate some plums without washing them. However, they were exposed to pesticides. After that, I was sick all day and I continuously vomited. What was the reason behind that?”. The teacher redirects this question to other students and they come to the conclusion that the reason behind this incident is eating plums without washing them. Teacher asks if other students also have similar experiences. Another student comments as "We ate some fish and felt unwell. My father thought that we got poisoned and took us to a hospital. Our stomachs were washed out by gastric lavage and we were given serum in the hospital. However, we had washed our fish. Why did this incident happen?” The teacher discusses this question with other students and concludes that the fish was not fresh and this was the reason behind this incident. The teacher stresses that students need to wash their foods, as well as pay attention to their freshness; otherwise they might get sick like their friends.

The teacher shows products like fruit juice and ice tea to the students and ask them to read out the "ingredient" part on them. The students ask "We have not heard any of these ingredients before. Why are they included in these products?" to their teacher. The teacher asks if students have any predictions about this issue. They are expected to give answers like "to make foods taste better" or "to prevent the foods to go off rapidly". The teacher explains that these are called additives, some of them are added to make foods taste better and some are added to extend the shelf life of these products. And then s/he asks if these products are good or bad for our body. It is predicted that most students will conclude that these products are harmful and can make them sick when consumed. The teacher states that "These products are harmful and we need to consume foods that do not have additives as much as possible”. The students ask how they can preserve their food without additives. The teacher asks if students know how people preserved their food in old times. One student mentions sun-drying by giving examples of their grandmothers of sun-drying peppers during summer times. Another student states making conserve cans and deep freezing of foods by giving examples from their mothers. Others mention dry-salting by giving examples of cheese, pickles and vine leaves being dry-salted. The teacher asks students "How is it possible to preserve milk in carton boxes while the milk at home easily gets spoiled in two days?". S/he shows the "ingredients" part on the milk box and make them observe that there are no additives in milk. S/he explains that milk is pasteurized and explains pasteurization as a method of preservation. Pasteurization is done as a shock process by heating and cooling the milk in very high and low temperatures in a very short period of time. The teacher asks students "Did you check the date of expiry for food you brought?" and instructs them to search for the date of expiry on the package of products they brought. S/he asks students "What happens when we consume products after their date of expiry?”. The students are expected to answer as getting sick. The teacher underlines the importance of date of expiry by commenting that "We need to pay attention to the expiry date of products, as well as their freshness and cleanliness when buying them. We should not buy and use products if their date of expiry has passed as they would be harmful for our body." A student asks about DoE (STT) and RBbD (TETT). Teacher explains that DoE is abbreviation of Date of Expiry, and RBbD is abbreviation for Recommended Best by Date; and these are the same with date of expiry.

The teacher may ask "Who constructs and fix buildings?" Students are expected to answer as "construction workers". The teacher explains that "There are some elements in our food that heals our wounds, make babies grow up and make our hair grow. These are called proteins. Which foods you brought do you think has protein in it?" and instruct them to write the answer in their worksheets. Students are expected to write milk and dairy products thinking that babies consume a lot of milk to grow up. The teacher makes students read their answers out loud. S/he states that "Babies grow up drinking milk because milk is rich in proteins. Proteins are constructive and regenerative. They heal our wounds and 
make our hair and nails grow. What other products you brought are in protein group?" Students are expected to cheese in the protein group as it is made of milk. The teacher also explains that egg is in protein group, too. $\mathrm{S} / \mathrm{he}$ states that apart from the food they brought, foods like meat, lentils and yoghurt are rich in proteins. Together with student answers, teacher checks the respective parts in the form about the trip and corrects the wrong answers.

The teacher rubs the walnut $\mathrm{s} / \mathrm{he}$ brought on a piece of paper. The paper becomes transparent. S/he asks students "Why did the walnut make the paper transparent?". Students are expected to answer that the paper became transparent as a result of the fat in walnut. Teacher asks students if any of them experienced a similar incident. One student gives an example from the daily life commenting that "Pastries we wrapped in a piece of newspaper also made this paper transparent. This happened because of the fat in the pastry." The teacher accepts similar answers from students. S/he instructs the students to write the foods which they consider in fat group on the form about the trip. The students rub each food they brought on a piece of paper and write down those who make the paper transparent. Food like pastries, olives and walnuts are expected to be written in the respective part. A student asks to the teacher "When we rub tomatoes, the paper also become transparent. Is there fat in tomato?”. The teacher explains that tomato did not make the paper transparent, but just made it wet because it has a lot of water in it. After observing the transparent paper rubbed by walnuts and wet papers rubbed by tomato, differences are aimed to be understood by students. The teacher explains that fats are energizing, make papers transparent when rubbed, shape our body, and protect it from damages. S/he stresses that "Fats are primarily for energizing and that is the reason for considering them in energizer foods group. There is another type of food that is energizing. We will learn about them soon."

The teacher asks the class "What is the function of vitamins for our body?”. The students are expected to say that vitamins protect our body as they know vitamins from their daily life. Apart from this, the teacher underlines that vitamins are also responsible as regulator in our body and they protect us from diseases. S/he instructs the students to write which foods they brought have vitamins on the form about the trip. One student asks the teacher "Isn't there a small amount of vitamin in every food? Is there any food that does not contain any vitamin?". The teacher answers as "Of course each food contains certain amount of vitamin. However, some foods contain more vitamins than others, that is why we consider them in vitamin group.” Among the food students brought, tomato, cucumber and apple are noted in vitamin group by the class. Students read out their answers on the form about the trip and correct answers among them are accepted, whereas the wrong ones are corrected.

The teacher states that "There are other foods that give us energy. These are also considered as energizers like fats.", and instructs them to write "What these foods can be?" on the form about the trip. Students are expected to write foods that are not listed under vitamin, fat and protein groups on the form about the trip. The teacher asks students to read out their answers. Correct answers are found as bread, cake, honey, jam and chocolate cream. S/he explains that deserts and pastries are considered in carbohydrates group and carbohydrates are also energizers like fats. After that, one student asks "Can we get energy from an orange? Do we have to eat food from fat and carbohydrate groups to get energy?" to teacher. The teacher states that there is carbohydrates and fat in almost every food; however, foods should be categorized on the basis of which nutrient group they contain.

The teacher asks the students "Which foods have water in them?", and instructs them to write their thoughts on their worksheets. The teacher makes students read out what they wrote. Students are expected to write all foods except bread. Teacher states that water is put into the bread when making it. S/he explains that "All foods have minerals, as well as water. Minerals and water are responsible as regulators in our body. If we look at the label on the bottled water, we can see which minerals it has." The teacher makes students read out label of the bottled water they brought.

After everybody writes down foods they brought are in which nutrient group, $\mathrm{s} / \mathrm{he}$ instructs students to read them out loud. Incorrect and missing parts are evaluated by the class.

After that, the breakfast is completed all together.

Results: After the completion of activities, students are instructed to verbally explain what they have learnd and fill in their worksheet. At the end of the lecture, the teacher explains that nutrients are necessary for our vital activities; among these nutrients, proteins are constructive-regenerative; carbohydrates and fats are energizers; vitamins, water and minerals are regulative; water and minerals exist in all types of nutrients. The teacher concludes the course after emphasizing the importance of freshness, naturalness and cleanliness of nutrients are very critical for a healthy life.

In-class activities after the trip: After the completion of the trip, several in-class activities are needed to revise, summarize and reinforce the lecture. Revision can be done through knowledge maps and concept maps.

Assessment and Evaluation: Student statements on worksheets, concept maps and knowledge maps can be used for evaluation. Diagnostic trees and structured grids are distributed among students and solved to reinforce the lecture, as well as for assessment. 


\title{
Alternative Measuring Instruments
}

\author{
Nutrients and their Characteristics Worksheet
}

I am Having My Breakfast

Dear students; as you know, we have breakfast every day. Today, we will have our breakfast with foods we brought for this lecture. In this regard, let's finish our breakfast by completing the questions below.

1. Write down the names of food you brought for breakfast.

2. Did you wash your food? If so, why did you wash them?

3. Do you think foods you brought for breakfast are fresh? What happens if they are not fresh?

4. Which food or foods you brought for breakfast do you think can be considered in protein group?

5. Which food or foods you brought for breakfast do you think can be considered in fat group?

6. Which food or foods you brought for breakfast do you think can be considered in vitamin group?

7. Which food or foods you brought for breakfast do you think can be considered in carbohydrates group?

8. Which food or foods you brought for breakfast is consisted of water?

9. Write what you have learnt from this lecture below.
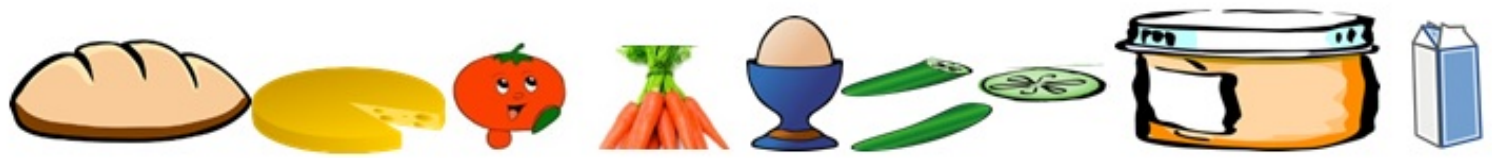


\section{A Concept Map}
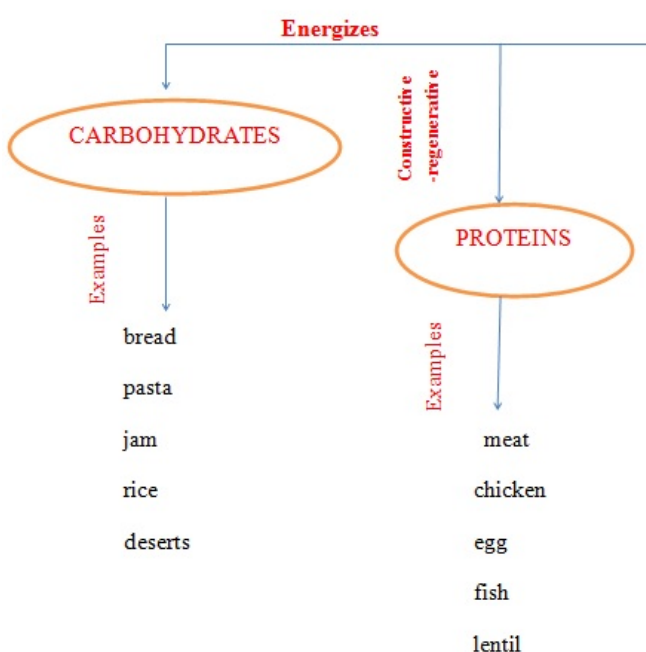

NUTRITION TYPES

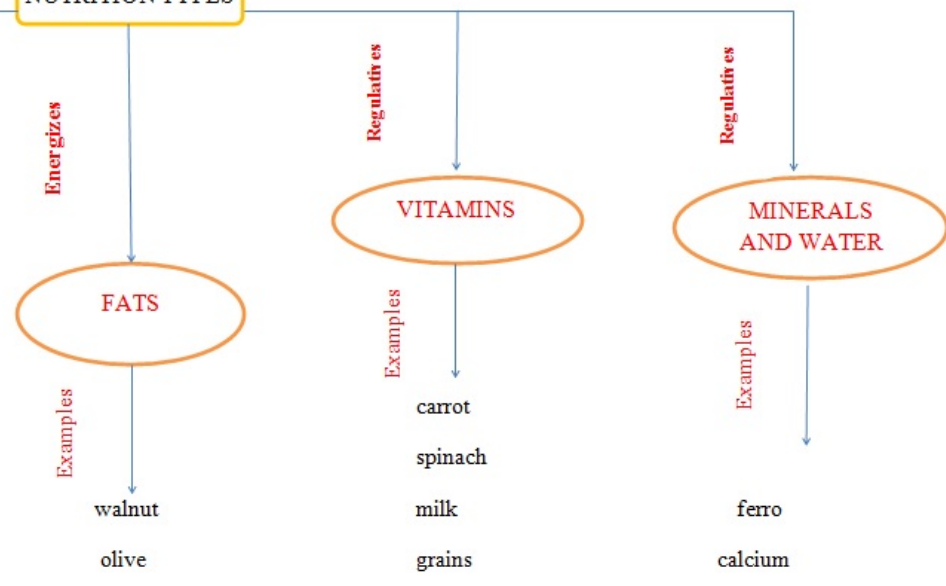

hazelnut

all nutriens

sunflower

A Diagnostic Tree

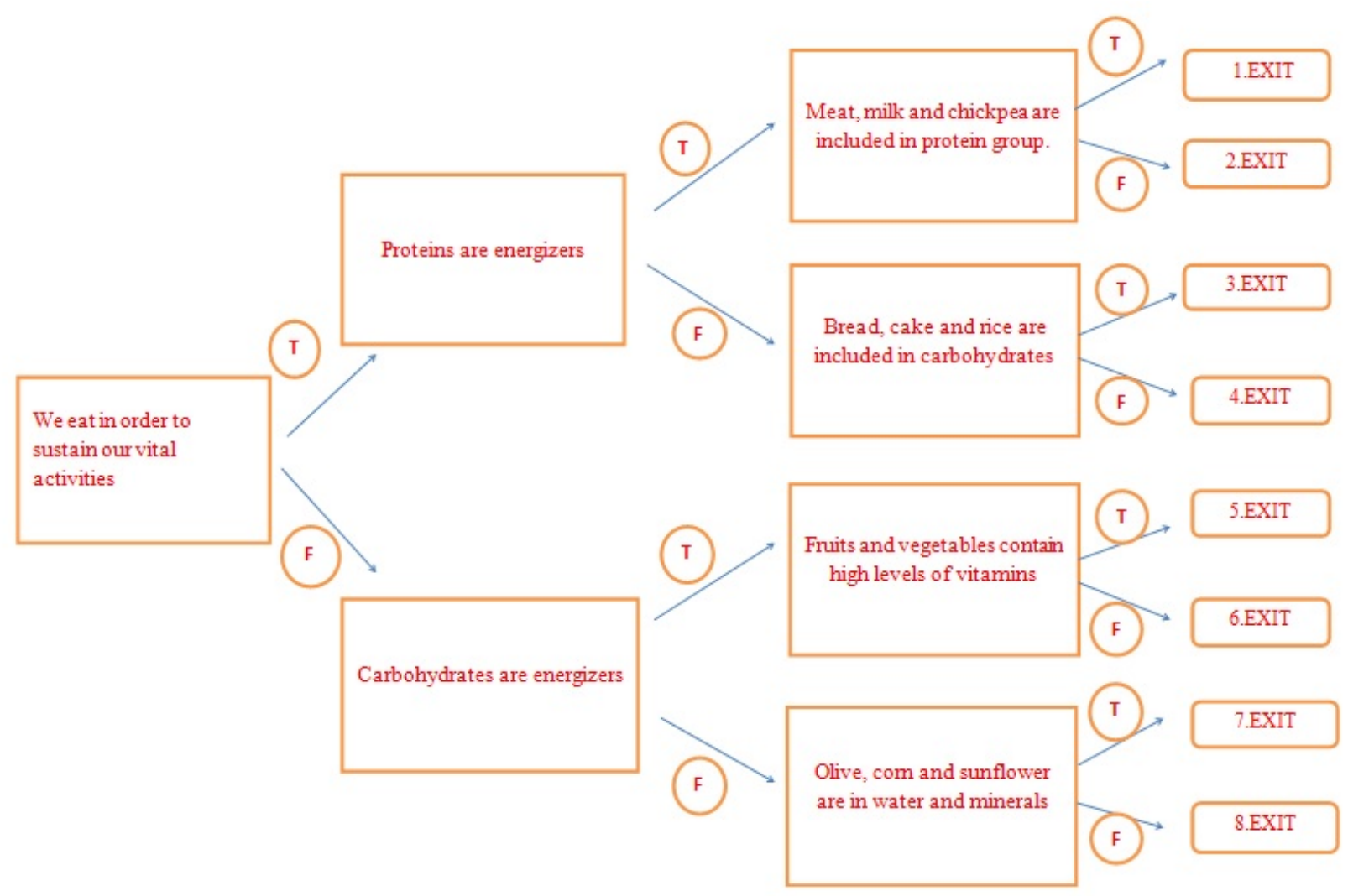


Find the correct pathway to exit in the diagnostic tree pathway given above. Write down true and false expressions of questions fromthe diagnostic tree below.

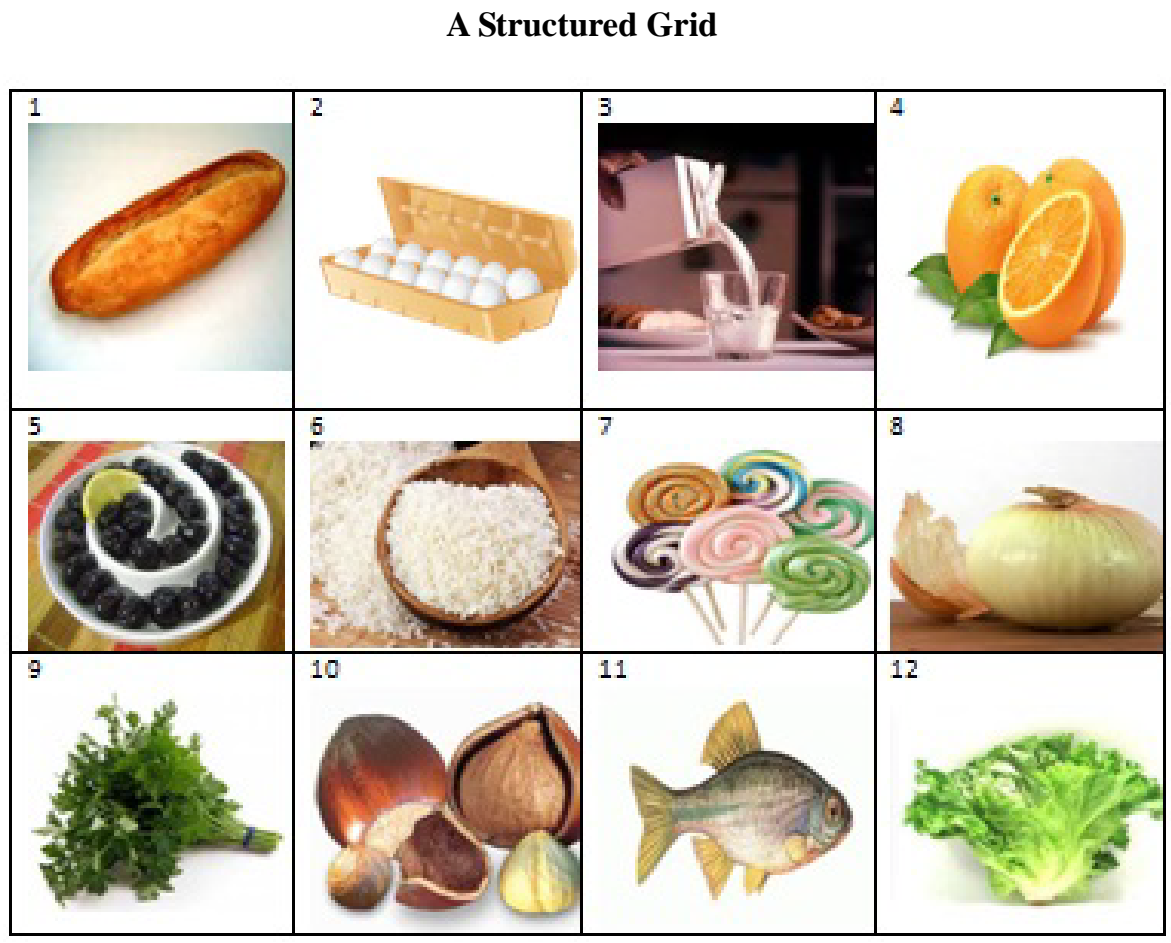

Please answer the following questions using the table below.

1. Which foods contain which vitamins?

2. Which foods are rich in carbohydrates?

3. Which foods are rich in Proteins?

4. Which foods are rich in fat?

5. Which foods contain water and minerals? 


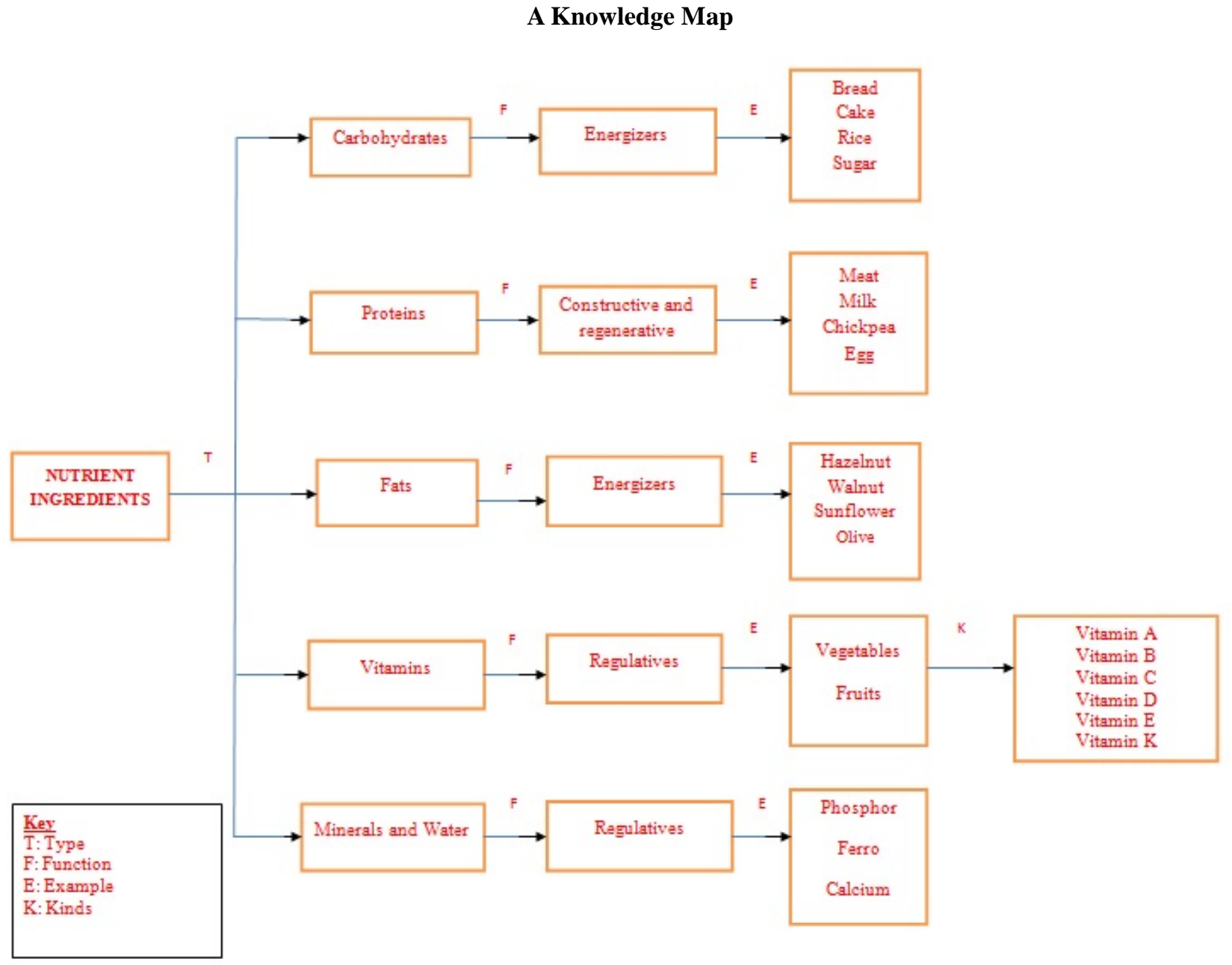

\section{REFERENCES}

[1] Cantürk Günhan, B. \& Başer, N. Probleme Dayalı Öğrenme Yönteminin Öğrencilerin Matematiğe Yönelik Tutumlarına ve Başarılarına Etkisi. Abant İzzet Baysal Üniversitesi Eğitim Fakültesi Dergisi, 8 (1), 119- 134, 2008.

[2] Armağan, B. İlkokul Dördüncü Sınıf Fen Öğretiminde Okul Dış1 Öğrenme Ortamları: Bir Eylem Araştırması. YayınlanmamışYüksek Lisans Tezi, Dokuz Eylül Üniversitesi, İzmir, 2015.

[3] Bakioğlu, B. \& Karamustafaoğlu, O. Okul Dışı Ortamlarda Fen Eğitimi: Diyaliz Merkezine Teknik Bir Gezi. Turkish Journal of Education, 3 (2), 15- 26, 2014.

[4] Balkan Kıyıcı, F. \& Atabek Yiğit, E. Sınıf Duvarlarının Ötesinde Fen Eğitimi: Rüzgâr Santraline Teknik Gezi. International Online Journal of Educational Sciences. 2 (1), 225- 243, 2010.

[5] Bodur, Z. Sınıf Dıșı Etkinliklerin Güneș Sistemi ve Ötesi Ünitesinde Ortaokul Yedinci Sınıf Öğrencilerinin Akademik Başarıları, Bilimsel Süreç Becerileri ve Motivasyonları
Üzerine Etkisi. Yayınlanmamış Yüksek Lisans Tezi, Marmara Üniversitesi, İstanbul, 2015.

[6] Bozdoğan, A.E. Bilim ve Teknoloji Müzelerinin Fen Öğretimindeki Yeri ve Önemi. Yayınlanmamıș Doktora Tezi, Gazi Üniversitesi, Ankara, 2007.

[7] Ertaş, H., Şen, A.İ. \& Parmaksızoğlu A. The Effects of Out-of School Scientific Activities on 9th Grade Students 'Relating the Unit of Energy of Daily Life. Necatibey Faculty of Education Electronic Journal of Science and Mathematics Education, 5 (2), 178-198, 2011.

[8] Yorulmaz, E. Sosyal Bilgiler Dersi Kapsamında Okul Dışı Çevrelerin Kullanımı: Çorum Yatılı Arkeoloji Müzesinde Bir Gün. Yayımlanmamış Yüksek Lisans Tezi, Cumhuriyet Üniversitesi, Sivas, 2016.

[9] Bozdoğan, A.E. Planning and Evaluation of Field Trips to Informal Learning Environments: Case of the Energy Park. Journal of Theory and Practice in Education, 4 (2), 282-290, 2008.

[10] Maarschalk, J. Scientific Literacy and Informal Science Teaching. Journal of Research in Science Teaching 25(2), 135- 146, 1988.

[11] Tamir, P. Factors Associated with the Relationship Between Formal, Informal, and Non formal Science Learning. Journal 
of Environmental Education, 2(2), 34-42, 1990.

[12] Erten, Z. Fen Bilgisi Dersine Yönelik Okul Dışı Öğrenme Ortamları Etkinliklerinin Geliştirilmesi ve Öğrencilerin Bilimsel Süreç Becerilerine Etkisinin Değerlendirilmesi. Yayımlanmamış Yüksek Lisans Tezi. Erzincan Üniversitesi, Erzincan, 2016.

[13] Panizzon, D. \& Gordon, M. Mission Possible: A Day of Science, Fun and Collaboration. Australian Primary Junior Science Journal, 19 (2), 9-14, 2003.

[14] Laçin Şimşek, C. Okul Dışı Öğrenme Ortamları ve Fen Eğitimi. C. Laçin-Şimșek (Editör), Fen öğretiminde okul dıș1 öğrenme ortamları (1.Bask1.), s. 1-23. Ankara: PegemA, 2011.

[15] Demircioğlu, G. Lise II Asitler ve Bazlar Ünitesi ile İlgili Rehber Materyal Geliştirilmesi ve Uygulanmasi. Yayımlanmamış Doktora Tezi, Karadeniz Teknik Üniversitesi, Trabzon, 2003.

[16] Devecioğlu, Y. Fizik Öğretmen Adaylarına Rehber Materyal Geliştirme ve Uygulama Becerilerinin Kazandırılmasına Yönelik Bir Yaklaşım. Yayımlanmamış Yüksek Lisans Tezi, Karadeniz Teknik Üniversitesi Fen Bilimleri Enstitüsü, Trabzon, 2004.

[17] Bozdoğan, A.E. Eğitim Amaçlı Gezilerin Planlanmasına İlişkin Fen Bilgisi Öğretmen Adaylarının Uygulamaları: Altı Farklı Alan Gezisinin Değerlendirilmesi. Kuram ve Uygulamada Eğitim Bilimleri, 12(2), 1049-1072, 2012.

[18] Griffin, J., \& Symington, D. Moving from Task-Oriented to Learning Oriented Strategies on School Excursions to Museums. Science Education, 8 (1), 763-779, 1997.

[19] Orion, N., \& Hofstein, A. Factors That Influence Learning During a Scientific Field Trip in a Natural Environment. Journal of Research in Science Teaching, 31(10), 1097-1119, 1994.

[20] Kisiel, J. Understanding Elementary Teacher Motivations for Science Fieldtrips. Science Education, 89(6), 936-955, 2005.

[21] Thomas, G. Facilitator, Teacher, or Leader? Managing Conflicting Roles in Outdoor Education. Journal of Experiential Education, 32(3), 239-254, 2010.
[22] MEB (Milli Eğitim Bakanlığı). İlköğretim Kurumları (İlkokullar ve Ortaokullar) Fen Bilimleri Dersi Öğretim Programı. T.C. Milli Eğitim Bakanlığı Talim ve Terbiye Kurulu Başkanlığı, Ankara, 2013.

[23] Tekkumru K1sa, M. Development and Implementation of a "Science Center Learning Kit" Designed to Improve Student Outcomes from an Informal Science Setting, Unpublished Master Dissertation, Boğaziçi University, Istanbul, 2005.

[24] Yardımcı, E. Yaz Bilim Kampında Yapılan Etkinlik Temelli Doğa Eğitiminin İlköğretim 4 ve 5. Sinıftaki Çocukların Doğa Algılarına Etkisi. Yayımlanmamış Yüksek Lisans Tezi, Abant İzzet Baysal Üniversitesi, Bolu, 2009.

[25] Yavuz, M. Fen Eğitiminde Hayvanat Bahçelerinin Kullanımının Akademik Başarı ve Kaygıya Etkisi ve Öğretmen- Öğrenci Görüşleri. Yayımlanmamış Yüksek Lisans Tezi, Sakarya Üniversitesi, Sakarya, 2012.

[26] Özsevgeç, T. Kuvvet ve Hareket Ünitesine Yönelik 5E Modeline Göre Geliştirilen Öğrenci Rehber Materyalinin Etkililiğinin Değerlendirilmesi, Türk Fen Eğitimi Dergisi, 3(2), 36-48, 2006.

[27] Metin, M. Eğitimde Bilimsel Araştırma Yöntemleri. 2. Bask1, Pegem Akademi Yayınları, 2015.

[28] Yıldırım, A. \& Şimşek, H. Sosyal Bilimlerde Nitel AraştırmaYöntemleri. Seçkin Yayıncılık, Ankara, 2011.

[29] Bozdoğan, A. E., \& Kavc1, A. Sınıf Dışı Öğretim Etkinliklerinin Ortaokul Öğrencilerinin Fen Bilimleri Dersindeki Akademik Başarılarına Etkisi. Gazi Eğitim Bilimleri Dergisi, 2 (1), 13- 30, 2016.

[30] Morag, O., \& Tal, T. Assessing Learning in the Outdoors with the Field Trip in Natural Environments (FINE) Framework. International Journal of Science Education,34(5), 745 - 777, 2012.

[31] Tatar, N., \& Bağrıyanık, K.E. Fen ve Teknoloji Dersi Öğretmenlerinin Okul Dış1 Eğitime Yönelik Görüşleri. İlköğretim Online, 11(4), 883 - 896, 2012.

[32] DeWitt, J., \& Storksdieck, M. A Short Review of School Field Trips: Key Findings from the Past and Implications for the Future. Visitor Studies, 11(2), 181 - 197, 2008. 